\title{
THE INFLUENCE OF E-SERVICE QUALITY TOWARD E-SATISFACTION, E-TRUST, E-WORD OF MOUTH AND ONLINE REPURCHASE INTENTION: A STUDY ON THE CONSUMERS OF THE THREE-STAR HOTELS IN LAMPUNG
}

\author{
Saodin* \\ Business Administration, Faculty of Administrative Sciences, University of Brawijaya, \\ Malang, Indonesia \\ Suharyono, Arifin Zainul, Sunarti \\ Faculty of Administrative Sciences, University of Brawijaya, Malang, Indonesia \\ *E-mail: saodin53@gmail.com
}

\begin{abstract}
The development of business through internet media (e-business) is increasingly prevalent throughout the world. Information and communication technology has also caused borderless relations and caused significant social, economic and cultural changes to occur so quickly. This study aims to examine and explain the effect of electronic service quality on electronic satisfaction, electronic trust, e-word of mouth and online repurchase intention. The survey method was used in this study and for the study sample there were 142 respondents who were hotel consumers who had stayed at one of the three-star hotels in Lampung Province, Indonesia. The research location is 15 three star hotels in Lampung Province, which consists of 13 districts and 2 cities. The questionnaire is the main instrument for collecting primary data. The data analysis used is descriptive statistics and Generalized Structured Component Analysis (GSCA). The results of this study are two hypotheses is not significant, namely esatisfaction and e-trust has no significant effect on e-wom. The new finding in the results of this study is that there is a significant effect between e-wom on online repurchase intention, where prior study has no effect between the two variables on online repurchases on the hotel website. The new finding of this study are significant effect between e-wom on the online repurchase intention, which was not previously found related to online purchases on the hotel website.
\end{abstract}

\section{KEY WORDS}

E-service quality, e-satisfaction, e-trust, e-wom, online repurchase intention, hotel consumer.

Indonesia's e-commerce has grown rapidly, this proven by the increasing of ecommerce retail sales year-over-year. The development of the internet on e-commerce market, directly or indirectly has changed the way people think and work time after time (Khan, Mahapatra, and Sreekumar, 2009). Life before the internet was people did traditional marketing which seller and buyer met one another, negotiated, and did transaction. However, the development of the internet has changed the way people run a business; they can run online business through the internet. Laudon and Traver (2002) defined e-commerce as the use of internet and websites for business transactions. E-commerce uses a website to transact or facilitate the sale of the products and online service. Information and Communications Technology (ICT), internet, and website are the important tools in ecommerce, and they have big impacts on the business world.

The high competition among hotels nowadays needs a reliable strategy to attract the customers by giving free promo airport shuttle, discount, and many more. These have been applied by many e-commerce on hotel industries either one-star or five-star hotels. In a customer-oriented business, the service quality contributes the success of the company. If it is not prioritized, the customers will move to others. The hotel practitioners see the internet as a tool to market the products, without geographical boundaries and time constraints (Huizingh, 2000). Through the internet, the consumers will easily get the information and 
capable to communicate with the service providers directly whenever and wherever. Walsh, Hennig-Thurau, Bornemann and Sassenberg (2010) have stated that the internet provides many ways to acquire information related to products or services from other consumers.

A study from Lee, Guillet and Law (2012) following the footsteps of airlines, the hotel industry recently uses more internets for its distribution. In Indonesia, Online travel Agent (OTA) such as Traveloka, Tiket.com, pegi-pegi and others, had grown rapidly (jpnn.com). Therefore, a good OTA must be able to improve service to the consumers in order that they will repurchase intention. Website and social media are part of the internet which capable to create a new era for the company to interact and engage their customers (Godey et al., 2016). Through the rapid expansion in the use of mobile devices and the wireless networks development penetrating cellular services in every aspect of life. Various cellular services (mobile applications, cellular instant messaging, mobile banking service and entertainment) have changed the way people shop, interact and even live. It is because the internet is crucial in disseminating an effective information about both product and services, therefore eword of mouth considered as an influential market in terms of social networking sites (Murtiasih, Sucherly and Siringoringo, 2013). Before buying any kinds of product or service, consumers seek for information on the internet. Internet provides different platform for blogs, forum discussion, shopping/ reviews/ websites (Erkan and Evans, 2014 ).

At a recent time, many hotels especially four-star and five-star hotels have already provide online ordering service. However, small to medium sized hotels (motels or inns) are still booked manually by phone because the owner feel that the online ordering service is not needed yet. The use of information technology has not only changed the nature of services, but also it has changed the process of providing services. E-service quality can be defined as a measurement of the effectiveness and efficiency of the website performance which can be accepted by customers with its function to support them in getting information, precise in doing transaction, success to deliver the product and service (Zeithaml, Parasuraman and Malhotra, 2002). The capability of hotel industry to give qualified online service will be able to improve customer satisfaction. This was confirmed by Swaid and Wigand (2007) who indicated that by giving superior e-servqual, consumer satisfaction and loyalty will increase. Both consumer satisfaction and trust has a positive influence toward positive WOM for hotel consumers. Repurchase intention appears due to consumer satisfaction, showing loyalty and provide positive recommendations (positive WOM). This is in line with Kurtz and Clow (1998).

Several studies showed that by improving service quality and customer satisfaction would affect hotel performance (Babakus et al, 2004). Therefore, maximizing customer satisfaction is one of the key factors to be successful. In order to maintain the quality of long term relationship, the website reservation must prioritize customer satisfaction. Zhang (2009) has found that conducting transactions online was very vulnerable and difficult to acquire. Moreover, trust allowed companies to trust others in organizing and using resources effectively in creating added value (Jasfar, 2002).

The competition among hotels in Lampung is getting tighter recently, mainly due to the fact that in 2017, some hotels open some branches there. This situation forced a three-star hotel management to further improve the quality of the services to customers in order to maintain a large number of customers. Lampung currently has 15 three-star hotels which use website as a marketing tool. The website serves as a tool to introduce the hotel products to consumers as well as promoting the special event offered. Furthermore, a website is used for communication between hotel and consumer, where consumer can make internet booking and can give question or criticism as an input. Thus, this study wants to reveal whether the phenomenon occurred is a gap between consumer expectations and perceptions, especially on three-star hotel booking websites in Lampung.

\section{LITERATURE REVIEW}

E-ServQual was developed in order to evaluate a service from internet network. EService Quality can be defined as an extension of a site to facilitate some activities such as 
shopping, purchasing and distributing effectively and efficiently (Chase, Jacobs, and Aquilano, 2006). E-service quality has an important role to create perceived value in online shopping environment. Value perceived by consumers is the evaluation by comparing benefits that they obtain from a service provided and their sacrifice to obtain the products.

The measurement of e-service quality variables in this inquiry refers to a study from Wolfinbarger and Gilly (2003), which was frequently used in B2C and C2C e-commerce studies. The following are the eight e-service quality indicators which were later adopted in accordance with those applied to three-star hotels:

1) The appearance of the website, 2) ease of use of web, 3) suitability of the product information presented and accuracy, 4) having a high technical function, 5) including website facility which provides a sense of security, either in terms of payments, or personal data from the consumers, 6) ability in providing service properly, 7) including company shrewdness in solving problems, 8) individual desires to help and answer questions from consumers.

E-satisfaction can be defined as an accumulation of satisfaction acquired by the consumers on every purchase, and experience to consume goods or services time after time on an online site (Kim et al., 2009). Moreover, Zeithaml et al. (2013) have stated that this satisfied consumer has a tendency to repurchase, and recommend goods or services. Meanwhile, dissatisfied customers will be more likely to move to other brands which means that they will not remain stay to this brand anymore (Anderson and Srinivasan, 2003). The factors which influence e-satisfaction in this study are taken from the results of the previous studies such as e-trust and service quality (Kim, Jin and Swinney, 2009; Liao et al., 2011).

Yeh and $\mathrm{Li}$ (2009) has evaluated the user satisfaction with web-based self-service in three dimensions including information system and services. Lee (2005) has stated that esatisfaction is customer satisfaction with previous buying experience or behavior toward a website. A study of online consumers from Lin and Lekhawipat (2014) has revealed that the efficiency of shipping and website design had significant impact on e-satisfaction. In an online based business ventures, the efforts in order to satisfy the customers will be different. Furthermore, a marketer's duty is to adjust the difference so that the satisfaction with an online-based business can be achieved.

Olorunniwo et al., (2006) dan Cronia et al., (2000) have stated that e-satisfaction is measured based on five indicators as follows: 1) Suitability of benefits and sacrifice, 2) service capability in accordance with expectations, 3) delighted experience in using services, 4) right choices, and 5) overall satisfying service. Satisfied and guaranteed customers when accessing online services will increase the trust to reuse the service. It can be said that their satisfaction plays a positive and significant role toward the trust (Yeh and Li, 2009).

E-trust is crucial because logically online consumers will have a higher level of risk than those who have non-online transactions, in terms of shipping, payment and personal information. Therefore, online consumers will only transact with trusted e-commerce business. A study from Kim et al (2009) and Liao (2012) showed that e-trust as an important factor to shape e-loyalty through e-satisfaction. Therefore, this study will use e-trust as one of the factors to shape e-satisfaction and e-loyalty.

E-trust can be defined as a trust toward expectations in an online risk situation or consumers' attitude to receive vulnerabilities during the online transactions (Corritore et al., 2003). Komiak and Benbasat (2004) have seen trust from an emotional point of view. They defined trust as the degree to which a person feels safe and confident to someone. Meanwhile, Eid (2011) have seen beliefs from emotional view and cognitive dimension, and defined trust as a person's willingness to receive vulnerability as a positive expectation, regarding intentions or behavior in specific situations on interdependence and risk. E-trust can be defined as the basis of the formation and maintenance relationship between customers and online sellers (Kim et al., in Giovanis and Athanasopoulou, 2014).

According to Jalilvand and Samiei (2012), e-word of mouth (e-WOM) as "negative or positive statements made by actual, potential or previous consumers related to product or company where the information is available for the people or institutions through the internet media". E-word of mouth (e-WOM) is considered to be the evaluation of face-to-face traditional communication to be more sophisticated through cyberspace, or an electronic 
media in computer networks that is widely used either for one way or reciprocal online communication. Gruen et al., (2006) has defined e-WOM as a mean of communication for sharing information related to product or service which has been consumed by consumers who do not know and meet before. A study from Jalilvand et al., (2012) showed that e-WOM influenced a consumer behavior before he decided to buy a product or service.

According to Dellarocas (2003), e-WOM message is important as a media for the consumer, in order to get the information related to product and service quality. Furthermore, this message is effective in reducing risk and uncertainty experienced by consumers when purchasing a product or service, therefore the purchase interest and buying decision of the consumers can be influenced (Goyette et al., 2012). Jeong and Jang (2011) has proved that no matter how sophisticated the product, and how promising it was, it would be meaningless if the consumers were not satisfied. By satisfying them, both companies and consumers would have a harmonious relationship, thus, a repeating order would occur.

Repurchase intention can be defined as an intention to repurchase a product twice or more either the same or different product (Weisberg et al., 2011). Repurchasing includes two characteristics such as intention and behavior. It is closely related to consumer's attitudes toward objects and previous behavior. A study from Astuti and Reusfian (2013) found that satisfaction was not directly related to repurchase. However, consumer satisfaction influenced repurchase behavior from psychological research view, in which satisfaction encouraged intention, while intention encouraged behavior. Therefore, repurchasing is one indicator of satisfaction and also the effect of purchases.

Chang, Lee, Chien, Huang and Chen (2010) have stated that there is a positive relationship between consumer experience toward a product and their tendency to repurchase a good product. Consumer intention in online purchases is the activity to purchase at an online store. The variable measurement of online repurchase intention based on customer behavior in purchasing, is showed by the high frequency of reservation or repurchasing, continuing to have a relationship with a service provider company, not willing to move to other companies.

According to Zhou et al., (2009) and Kim and Lennon (2013), online repurchase intention was measured based on: 1) I will repurchase on the website, 2) I will revisit the website, 3) I intend to recommend the online shopping sites to other people. This continuing relationship is characterized by maintaining relationship with three-star hotels unaffected by other persuasion. The intensity of reservation in hospitality services can be analogous to the repurchasing behavior for the companies. Thus, consumers' online repurchasing at the hotel is indicated by an increase in reservations.

Based on the literature review, the hypotheses of this study are formulated as follows.

$\mathrm{H} 1$ : E-Service quality has significant effect on e-Satisfaction;

H2: e-Service quality has significant effect on e-Trust;

H3: E-Service quality has significant effect on e-Word of mouth;

H4: E-service quality has significant effect on Online repurchase intention;

H5: E-satisfaction has significant effect on e-Trust;

H6: E-satisfaction has significant effect on e-Word of mouth;

$\mathrm{H7}$ : E-satisfaction has significant effect on Online repurchase intention;

H8: E-trust has significant effect on e-Word of mouth;

H9: E-trust has significant effect on Online repurchase intention;

H10: E-word of mouth has significant effect on Online repurchase intention.

\section{METHODS OF RESEARCH}

This study used a quantitative approach, with explanatory research (Neuman, 2006; Ferdinand, 2002; Singarimbun and Effendi, 2009). Explanatory research is an attempt to explain the variables and the relationship between exogenous variables, namely: e-service quality with endogenous variables, namely; e-satisfaction, e-trust, e-word of mouth and online repurchase intention. Cooper and Schindler (2006) have stated that a study which based on theory or hypothesis that will be used to test a phenomenon that occurs classified 
into explanatory research. The object of this research was a three-star hotel in Lampung Province. This research is about reservations (reorder) online through the hotel website.

In this study, samples were taken by purposive sampling, which is sampling with goals that have been determined with certain considerations. Lemeshow (1997) formula was used to determine the size of the sample. The total samples were 142 customers re-order in threestar hotels in Lampung Province and were over 17 years old. Furthermore, a set of questionnaires adopted from prior studies was used to collect the respondents' demographic information and respondents answers. The questionnaire was disseminated through Google forms, with details of eight indicators on e-service quality, five indicators on e-satisfaction, six indicators on e-trust, five indicators on e-wom, and five indicators to assess online repurchase intention were used. The scaling applied in this study is a 5-point Likert scale of 1-strongly agree, 2-agree, 3-neutral, 4-disagree, and 5-strongly disagree. The demographic variables questioned are gender, age, status, and education background of the respondents. Validity and reliability testing was conducted prior to using the instrument for data collection. Inferential statistical was used to prove the hypothesis proposed in this study by using Generalized Structured Component Analysis (GSCA).

\section{RESULTS AND DISCUSSION}

Hypothesis testing by using the testing criteria states that if the critical ratio $(C R) \geq t$ table $(t=2.00$, alpha $=5 \%)$, then it is stated that exogenous variables have significant effects on endogeneous variables. The testing results of the direct correlation are presented in Table 1 as follows. Meanwhile, the results of the research can be described as shown in Figure 1.

Table 1 - The result of hypothesis testing

\begin{tabular}{|c|c|c|c|c|c|}
\hline Exogeneous & Endogeneous & Estimate & SE & CR & Conclusion \\
\hline e-Service quality & e-Satisfaction & 0.816 & 0.014 & $59.87^{*}$ & Accepted \\
\hline e-Service quality & e-Trust & 0.719 & 0.060 & $11.95^{*}$ & Accepted \\
\hline e-Service quality & e-Word of mouth & 0.538 & 0.149 & $3.62^{*}$ & Accepted \\
\hline e-Service quality & Online repurchase intention & 0.138 & 0.040 & $3.48^{*}$ & Accepted \\
\hline e-Satisfaction & e-Trust & 0.190 & 0.065 & $2.92^{*}$ & Accepted \\
\hline e-Satisfaction & e-Word of mouth & 0.196 & 0.107 & 1.83 & Rejected \\
\hline e-Satisfaction & Online repurchase intention & 0.382 & 0.034 & $11.18^{*}$ & Accepted \\
\hline e-Trust & e-Word of mouth & 0.180 & 0.113 & 1.59 & Rejected \\
\hline e-Trust & Online repurchase intention & 0.146 & 0.038 & $3.81^{*}$ & Accepted \\
\hline e-Word of mouth & Online repurchase intention & 0.233 & 0.050 & $4.62^{*}$ & Accepted \\
\hline
\end{tabular}

Source: GeSCA analysis.

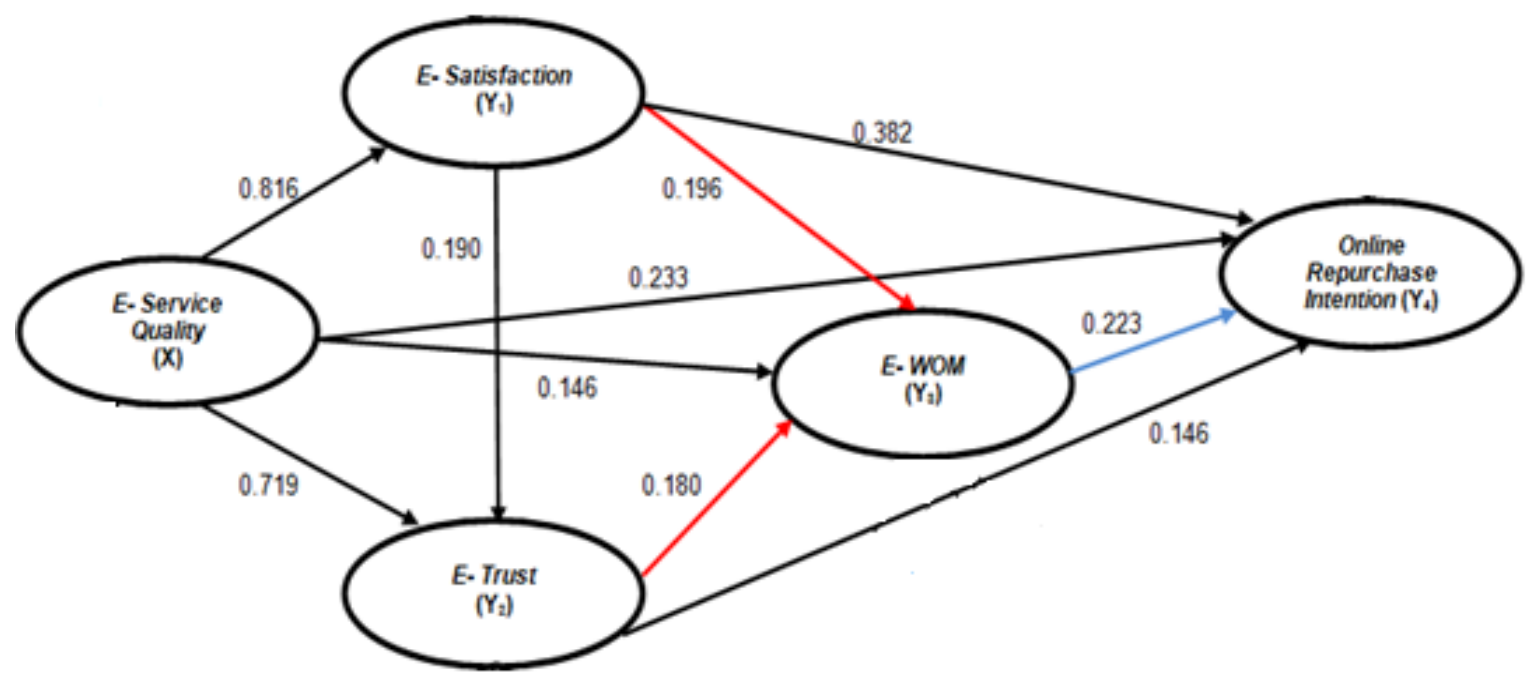

Figure 1 - The results of the research 
$\mathrm{H} 1$ : E-Service quality has significant effect on e-Satisfaction.

The results of GSCA analysis were obtained from the estimate value of 0.816 and the value of $\mathrm{CR}$ of $59.87^{*}$ (starred). This means that the value of $\mathrm{CR}>\mathrm{t}$-table $(\mathrm{t}=2,00$, alpha $=$ $5 \%)$, The decision is that the proposed $\mathrm{H} 1$ was empirically proven so that the hypothesis that has been formulated can be accepted in this research. This implies that e-service quality has significant effects on e-satisfaction. The estimated value with a positive sign indicates that the higher the e-service quality is felt by the respondents, the more satisfied they are with the re-reservation of a three-star hotel.

The results of this study also support the opinion of Parasuraman et al. (1988) who used the SERVQUAL model to measure customer perceptions and expectations, which the results of these measurements to determine the level of customer satisfaction. The findings of this study support the research conducted by Alireza et al. (2011) that directly service quality affects on customer satisfaction. Hu \& Huang (2011) and Alvin (2013) who stated that service quality has a positive and significant effect on satisfaction. Thus e-service quality and e-satisfaction are reflections of what respondents felt during interacting with the hotel website.

$\mathrm{H} 2$ : e-Service quality has significant effect on e-Trust.

The results of GSCA analysis were obtained from the estimate value of 0.719 and the value of $C R$ of $11.95^{*}$ (starred). This means that the value of $C R>t$-table $(t=2,00$, alpha $=$ $5 \%$ ), The decision is that the proposed $\mathrm{H} 2$ was empirically proven so that the hypothesis that has been formulated can be accepted in this research. This implies that e-service quality has significant effects on e-trust. The estimated value with a positive sign indicates that the higher the e-service quality is felt by the respondents, the greater the trust they are with the re-reservation of a three-star hotel.

The results of this study support the opinion that e-trust is the assessment of customers that service providers can be trusted (Gronroos, 2000; Gefen, 2000). The results of this study support and confirm the results of research by Corritore, et al. (2003) and Çerri (2012). This assessment can be used by comparing customer expectations with reality, or by comparing between three-star hotels and other three-star hotels.

H3: E-Service quality has significant effect on e-Word Of mouth.

The results of GSCA analysis were obtained from the estimate value of 0.538 and the value of $\mathrm{CR}$ of $3.62^{*}$ (starred). This means that the value of $\mathrm{CR}>\mathrm{t}$-table $(\mathrm{t}=2,00$, alpha $=$ $5 \%$ ), The decision is that the proposed $\mathrm{H} 3$ was empirically proven so that the hypothesis that has been formulated can be accepted in this research. This implies that e-service quality has significant effects on e-wom. The estimated value with a positive sign indicates that the higher the e-service quality is felt by the respondents, then the customer will recommend online reservations for three-star hotels to others via e-wom.

The results of this study confirm and expand the concept of Gronroos et al., (2000), namely quality E-service quality will leave a positive impression embedded in the minds of customers. The results of this study support the study conducted by Wang et al. (2003) and Alireza, et al. (2011). E-wom is the perception of a word of mouth / bitterness that is embedded in the minds of customers and works as a connector for information that influences the perception of a hotel website.

$\mathrm{H} 4$ : E-service quality has significant effect on Online repurchase intention.

The results of GSCA analysis were obtained from the estimate value of 0.138 and the value of $\mathrm{CR}$ of $3.48^{*}$ (starred). This means that the value of $\mathrm{CR}>\mathrm{t}$-table $(\mathrm{t}=2,00$, alpha $=$ $5 \%)$, The decision is that the proposed $\mathrm{H} 4$ was empirically proven so that the hypothesis that has been formulated can be accepted in this research. This implies that e-service quality has significant effects on online repurchase intention. The estimated value with a positive sign indicates that the higher the e-service quality is felt by the respondents, then the customer will conduct an online repurchase intention.

The results of this study support prior study conducted by Hume and Mort (2010) which states that service quality has a significant effect on repurchase intention. Liu (2012) states that electronic service quality has a significant positive effect on online repurchase intentions. Creating and developing online repurchase intentions requires a long process that takes a 
long time, starting from the first time buyers and to the next stage, making online repurchase intentions and customers who can persuade / influence other customers.

H5: E-satisfaction has significant effect on e-Trust.

The results of GSCA analysis were obtained from the estimate value of 0.190 and the value of $C R$ of $2.92^{*}$ (starred). This means that the value of $C R>t$-table $(t=2,00$, alpha $=$ $5 \%)$, The decision is that the proposed $\mathrm{H} 5$ was empirically proven so that the hypothesis that has been formulated can be accepted in this research. This implies that e-satisfaction has significant effects on e-trust. The estimated value with a positive sign indicates that the higher the e-satisfaction is felt by the respondents, the greater the trust they are with the rereservation of a three-star hotel.

The results of this study support the opinion of Oliver (1997). According to Siddiqi (2011), to gain trust, one group must believe that another group will take action that produces positive results for it. Therefore, in building customer trust, we need positive perceptions of results and to continue in the future. The results of this study support and confirm the results of the study by Kassim and Abdullah (2010), Cerri (2012) and Yap et al. (2012) which states that electronic satisfaction affects electronic trust. The respondent's trust in the hotel website is high, because the company applies strict staffing rules, to ensure the comfort and security of customer data. To avoid losses experienced by customers.

H6: E-satisfaction has significant effect on e-Word of mouth.

The results of GSCA analysis were obtained from the estimate value of 0.196 and the value of $C R$ of 1.83 . This means that the value of $C R<t$-table $(t=2,00$, alpha $=5 \%)$, The decision is that the proposed $\mathrm{H} 6$ was empirically proven so that the hypothesis that has been formulated can be rejected in this research. This implies that e-satisfaction has no significant effects on e-wom.

The results of this study confirm the research conducted by Swanson and Hsu (2009), Yang (2017), Serra-Cantallops, Ramon-Cardona \& Salvi (2018) and Anastasiei \& Dospinescu (2019) which states that e-satisfaction is not a guarantee for consumers to do ewom. The findings of this study are different from the research conducted by Dabholkar, et al. (2000), Hennig-Thurau et al. (2004), Brown et al. (2005), Olorunniwo et al. (2006) which states that e-satisfaction affects e-wom.

H7: E-satisfaction has significant effect on Online repurchase intention.

The results of GSCA analysis were obtained from the estimate value of 0.382 and the value of $\mathrm{CR}$ of $11.18^{*}$ (starred). This means that the value of $\mathrm{CR}>\mathrm{t}$-table $(\mathrm{t}=2,00$, alpha $=$ $5 \%$ ), The decision is that the proposed $\mathrm{H} 7$ was empirically proven so that the hypothesis that has been formulated can be accepted in this research. This implies that e-satisfaction has significant effects on online repurchase intention. The estimated value with a positive sign indicates that the higher the e-satisfaction is felt by the respondents, then the customer will conduct an online repurchase intention.

The results of this study support prior study by Chamcuntra and Fongsuwan (2014) which states that satisfaction increases purchase intention in the future. Besides that it also supports study conducted by Kassim and Abdullah (2010), Zeng et al. (2009), Choi, Kim and Lennon (2000), Cyr (2008) and Wen et al. (2011) that customer satisfaction with a service is positive, thus encouraging online repurchases intention.

H8: E-trust has significant effect on e-Word of mouth.

The results of GSCA analysis were obtained from the estimate value of 0.180 and the value of $C R$ of 1.59. This means that the value of $C R<t$-table $(t=2,00$, alpha $=5 \%)$, The decision is that the proposed $\mathrm{H} 8$ was empirically proven so that the hypothesis that has been formulated can be rejected in this research. This implies that e-trust has no significant effects on e-wom.

The results of this study support the prior study by Virgilio \& Antonelli (2017) which states that trust in online purchasing is the key to electronic communication by word of mouth (e-word of mouth), if customer trust is low then a negative impact on e- wom. The findings of this study are different from the results of study conducted by Sichtmann (2007) which states that customer trust is an important factor and trust has a significant effect on word of mouth behavior on online purchases. 
H9: E-trust has significant effect on Online repurchase intention.

The results of GSCA analysis were obtained from the estimate value of 0.146 and the value of $\mathrm{CR}$ of $3.81^{*}$ (starred). This means that the value of $\mathrm{CR}>\mathrm{t}$-table $(\mathrm{t}=2,00$, alpha $=$ $5 \%$ ), The decision is that the proposed H9 was empirically proven so that the hypothesis that has been formulated can be accepted in this research. This implies that e-trust has significant effects on online repurchase intention. The estimated value with a positive sign indicates that the higher e-trust of respondents, then the customer will conduct an online repurchase intention.

The results of this study support prior studies by Flavian et al. (2006), Gefen (2002), Li et al. (2006), Lim et al. (2006) and Qureshi et al. (2009) which states that trust has been found to be the main predictor of online repurchase intention.

H10: E-word of mouth has significant effect on Online repurchase intention.

The results of GSCA analysis were obtained from the estimate value of 0.233 and the value of $\mathrm{CR}$ of $4.62^{*}$ (starred). This means that the value of $\mathrm{CR}>\mathrm{t}$-table $(\mathrm{t}=2,00$, alpha $=$ $5 \%$ ), The decision is that the proposed $\mathrm{H} 10$ was empirically proven so that the hypothesis that has been formulated can be accepted in this research. This implies that e-wom has significant effects on online repurchase intention.

Matute, Polo-Redondo and Utrillas (2016) suggest that WOM is a person-to-person communication tool, between communicators and recipients, who consider information received about a brand, product, or service. Likewise, WOM has been defined as communication between consumers about a product, service, or company where the sources are considered independent of commercial influence (Litvin et al., 2008).

Empirically, the results of this study are new findings because there are no empirical studies that examine the effect of e-wom on online repurchase intention, especially on online purchasing services on hotel web sites.

\section{CONCLUSION}

This study has the main objective to investigate the extent to which online marketing can provide satisfaction and trust to customers, so they make repeat purchases. Of the six variables with ten tested hypotheses, there is one hypothesis was found, e-wom has a significant effect on online repurchase intention, shows that if consumers feel satisfied and believe in a service, they are happy to recommend the service to others (e-wom). The effect is that the customer will repurchase the service.

This study examines the behavior of customers, especially consumers of three-star hotels who visit in Lampung Province in relation to e-service quality and e-satisfaction obtained during interaction with three-star hotels in Lampung Province. Customer behavior includes aspects of e-satisfaction, e-trust, e-word of mouth, and online repurchase intention. The results of this study are expected to enrich the literature relating to customer behavior.

\section{REFERENCES}

1. Alireza, F., Ali, K., and Aram, F. (2011). How Quality, Value, Image, and Satisfaction Create Loyalty at an Iran Telecom. International Journal of Business and Management, 6 (8), 271-281.

2. Alvin, R. (2013). Effect of Service Quality and Product Quality to Corporate Image, Customer's Satisfaction and Customer Trust. IOSR Journal of Business and Management, 9 (6), 1-9.

3. Anastasiei, B., and Dospinescu, N. (2019). Electronic Word-of-Mouth for Online Retailers: Predictors of Volume and Valence. Sustainability, 11 (814), 1-18.

4. Anderson, R. E., and Srinivasan, S. S. (2003). E-Satisfaction and e-loyalty: a contingency framework. Psychology and Marketing, 20 (2), 123-138.

5. Astuti, R.D. and Rusfian, E. Z. (2013). Pengaruh E-Service Quality Terhadap Repurchase Intention Melalui Customer Satisfaction (Studi Pada Online Shop Gasoo Galore). FISIP UI, 1-19. 
6. Babakus, E., Bienstock, C., and Van Scottet, J.R. (2004). Linking Perceived Quality and Customer Satisfaction to Store Traffic and Revenue Growth. Decision Sciences, 35 (4), 713 - 737. DOI: 10.1111/j.1540-5915.2004.02671.x.

7. Brown, T. J., Barry, T. E., Dacin, P. A., \& Gunst, R. F. (2005). Spreading the word: Investigating antecedents of consumers' positive word-of-mouth intentions and behaviors in a retailing context. Journal of the Academy of Marketing Science, 33, 123138.doi:10.1177/0092070304268417.

8. Cerri, Shpetim. (2012). Exploring the Relationships among Service Quality, Satisfaction, Trust and Store Loyalty among Retail Customers. Journal of Competitiveness, 4 (4), 16 35. DOI:10.7441/joc.2012.04.02.

9. Chamcuntra, S., and Fongsuwan, W. (2014). Customer repurchase intention, trust and customer satisfaction influencing outsourced employees at kasikornbank bank publict company limites (Thailand). International Journal of Arts and Sciences, 7(3), 233-242.

10. Chang, L. Y., Lee. Y. J., Chien. C. L., Huang. C. L., and Chen. C. Y. (2010). The influence of consumer's emotional response and social norm on repurchase intention: a case of cigarette repurchase in Taiwan. The Journal of International Management Studies, 5 (2), 499-513.

11. Chase, R. B., Jacobs, F. R., and Aquilano, N. J. (2006). Production and operations management: manufacturing and services. 7th edition. Chicago: Irwin.

12. Choi, D. H.. Kim. S. I., Kim. S. H. (2000). Antecedents and behavioral consequences of customer satisfaction on internet retail store. International Center for Electronic Commerce: 9-18.

13. Cooper, D. and Schindler, P.S. (2006). Marketing Research. New York: McGraw Hill Companies Inc.

14. Corritore, C. L., Kracher, B., and Wiedenbeck, S. (2003). On-line trust: Concepts, evolving themes, a model. International Journal of Human Computer Studies, 58(6), 737758.

15. Cyr, D. (2008). Modeling Website Design Across Cultures: Relationship to Trust, Satisfaclion, and E-loyalty. Journal of Management Information Systems, 24(4), 47-72.

16. Dabholkar, P.A., Shepherd, C.D., and Thorpe, D.I. (2000). A Comprehensive Framework for Service Quality: An Investigation of Critical Conceptual and Measurement Issues Through a Longitudinal Study. Journal of Retailing, 76 (2), 139-173.

17. Dellarocas, C. (2003). The Digitization of Word-of-Mouth: Promise and Challenges of Online Feedback Mechanisms (March 2003). MIT Sloan Working Paper No. 4296-03. Available at SSRN: https://ssrn.com/abstract=393042.

18. Eid. M. L. (2011). Determinants of e-commerce customer satisfaction, trust, and loyalty in Saudi Arabia. Journal of Electronic Commerce Research, 12 (1), 78-93.

19. Erkan, I., and Evans, C. (2014). The Impacts of Electronis Word of Mouth in Social Media on Consumers Purchase Intentions. International Conference on Digital Marketing (ICODM), 5, 9-14.

20. Ferdinand, A. (2002). Metode Penelitian Manajemen: Pedoman Penelitian untuk skripsi, Tesis dan Disertai Ilmu Manajemen. Semarang: Universitas Diponegoro.

21. Flavian, C., Guinaliu, M., and Gurrea, R. (2006). The Role Playedby Perceived Usability, Satisfaction and Consumer Trust onWebsite Loyalty. Information \& Management (43), 114.

22. Gefen, D. (2000). E-commerce: The role of familiarity and trust. Omega: The International Journal of Management Science, 28 (6), 725-737.

23. Gefen, D., and Straub, D.W. (2004). Consumer trust in B2C e-commerce and the importance of social presence: experiments in e-products and e-services. Omega, 32(6), $407-424$.

24. Giovanis, A. N., and Athanasopoulou, P. (2014). Gaining customer loyalty in the e-tailing marketplace: the role of e-service quality, e-satisfaction and e-trust. Int. J. Technology Marketing, 9 (3), 288-304. 
25. Godey, B., Manthiou, A., Pederzoli, D., Rokka, J., Aiello, G., Donvito, R., Singh, R. (2016). Social media marketing efforts of luxury brands: Influence on brand equity and consumer behavior. Journal of Business Research, 69 (12), 5833-5841.

26. Goyette, I., Richard, L., Bergeron, J., and Martictte. F. (2012). E-WOM scale: Word-ofmouth measurement scale for eservice context. Canadian Journal of Administrative Sciences, 27(1), 5-23.

27. Grönroos, C., Helnomen, F., Isoniemi. K, and Lindholm, M. (2000). The NetOffer model: A case example from the virtual marketspace. Management Decision, 38(4), 243- 252.

28. Gruen, T., Osmonbekov, T., and Czaplewski, A.J. (2006). eWOM: The impact of customer-to-customer online know-how exchange on customer value and loyalty. Journal of Business Research, 59 (4), 449-456.

29. Hennig-Thurau, T., Gwinner, K.P., Walsh, G., and Gremler, D.D. (2004). Electronic word of mouth via Consumer-Opinion Platforms: What motivates customer articulation themselves on the internet?. Journal of Interactive Marketing, 18 (1), 38-52. DOI: 10.1002/dir.10073.

30. Hu, K.C., and Huang, M.C. (2011). Effect of Service Quality, Innovation and Corporate Image on Customer's Satisfaction and Loyalty of air Cargo Terminal. International Journal of Operations Research, 8 (4), 36-47.

31. Huizingh, Eelko, K.R.E. (2000). The Content and Design of Web Sites: An Empirical Study. Information and Management, 37, 123-134.

32. Hume, M., and Mort, G.S. (2010). The consequence of appraisal emotion, service quality, perceived value and customer satisfaction on repurchase intent in the performing arts. $\begin{array}{llll}\text { Journal of Services } & \text { Marketing, } 24 & \text { (2), 170-182. }\end{array}$ http://dx.doi.org/10.1108/08876041011031136.

33. Jasfar, F. (2002). Kualitas Hubungan (Relationship Quality) dalam Jasa Penjualan. Jurnal Riset Ekonomi dan Manajemen, 2 (3), 18-30.

34. Jalilvand, M.R. and Samiei, N. (2012). The effect of electronic word of mouth on brand image and purchase intention: An empirical study in the automobile industry in Iran. Marketing Intelligence and Planning, 30 (4), 460-476.

35. Jeong, E. and Jang, S. (2011). Restaurant experiences triggering positive electronic word-of-mouth (eWOM) motivations. International Journal of Hospitality Management, 30 (2), 356-366.

36. Kassim, N., and Abdullah, N.A. (2010). The effect of perceived service quality dimensions on customer satisfaction, trust, and loyalty in e-commerce settings: a cross cultural analysis. Asia Pacific Journal of Marketing and Logistics, 22 (3), 51-371. DOI: 10.1108/13555851011062269.

37. Khan, M.S., Mahapatra, S.S., and Sreekumar. (2009). Service quqlity evaluation in internet banking: an empirical study in India. International Journal of Indian Culture and Business Management, 2 (1), 30-46.

38. Kim, J., Jin, B., and Swinney, J.L. (2009). The role of etail quality, e-satisfaction, and etrust in online loyalty development process. Journal of Retailing and Consumer Services, 16: 239- 247.

39. Kim. J. and Lennon, S. J. (2013). Effects of reputation and website quality on online consumers' emotion, perceived risk and purchase intention: Based on the stimulusorganism-response model". Journal of Research In Interactive Marketing, 7 (1), 33-56.

40. Kurtz, D.L., and Clow, K.E. 1998. Service Marketing. New York: Wiley \& Sons.

41. Laudon, K. C and Traver, C. G. (2002). E- Commerce, Business Technology, Society. Boston: Addison Wesey.

42. Lee, H. A., Guillet, B. D., and Law, R. (2012). An examination of the relationship between online travel agents and hotels: A case study of choice hotels international and expedia.com. Focus on Information Technology, 54 (1), 95-107.

43. Lee, M.L. (2005). The impact of perceptions of interactivity on customer trust and transaction intentions in mobile commerce. Journal of Electronic Commerce Research, 6 (3), 165-80. 
44. Lemeshow, S. (1997). Besar Sampel dalam Penelitian Kesehatan. Yogyakarta: Gadjah Mada University.

45. Li, D., Browne, G. J., and Wetherbe, J. C. (2006). Why Do InternetUsers Stick with a Specific Web Site? A Relationship Perspective. International Journal of Electronic Commerce, 10(4), 105-141.

46. Liao, K.H. (2012). The Casual Effects of Service Quality, Brand Image, Customer Satisfaction on Customer Loyalty in the Leisure Resort Enterprise. China-USA Business Review, 11 (5), 631-642.

47. Lim, K., Sia, C. L., Lee, M. K. O., and Benbasat, I. (2006). HowDo I Trust You Online, and If So, Will I Buy? An EmpiricalStudy on Designing Web Contents to Develop Online Trust. Journal of Management Information Systems, 23(2), 233-266.

48. Lin, C. and Lekhawipat, W. (2014). Factors affecting online repurchase intention. Industrial Management and Data Systems, 114 (4), 597-611.

49. Litvin, S.W., Goldsmith, R.E.and Pan, B. (2008). Electronic word-of-mouth in hospitality and tourism management. Tourism Management, 29(3), 458-468.

50. Liu, T.H. (2012). Effect of E-service Quality on Customer Online Repurchase Intention. Lynn University.

51. Matute, J., Polo-Redondo, Y., and Utrillas, A. (2016). The influence of EWOM characteristics on online repurchase intention: Mediating roles of trust and perceived usefulness. Online Information Review, 40 (7), 1090-1110, https://doi.org/10.1108/OIR11-2015-0373.

52. Murtiasih, S., Sucherly., and Siringoringo, H. (2013). How word of mouth influence brand equity for automotive products in Indonesia. Procedia - Social and Behavioral Sciences, 81, 40-44. DOI.10.1016.j.sbspro.2013.06.384.

53. Neuman, W.L. (2006). Social Research Methods. London: Needham Heights, Allyn and Bacon.

54. Oliver, R. L. (1997). Satisfaction: A Behaviourial Perspective On The Consumer. New York: McGrawrHill Companies, Inc.

55. Olorunniwo, F., Hsu, M.K., and Udo, G.J. (2006). Service quality, customer satisfaction, and behavioral intention in the service factory. Journal of Services Marketing, 20 (1), 5972.

56. Parasuraman, A., Zeithaml, V.A and Berry, L.L. (1988). A Conceptual Model of Service Quality and its Implications for Future Research, Journal of Marketing, 49 (Fall), 41-50.

57. Qureshi, I., Fang, Y., Ramesy, E., McCole, P., Ibboston, P., and Compeau, D. (2009). Understanding Online Customer Repur-chasing Intention and the Mediating Role of Trust: An Empiricallnvestigation in Two Developed Countries. European Journalof Information Systems, 18(3), 205-222.

58. Serra-Cantallops, A., Ramon-Cardona, J., and Salvi, F. (2018). The impact of positive emotional experiences on eWOM generation and loyalty. Spanish Journal of Marketing ESIC, 22 (2), 142-162, https://doi.org/10.1108/SJME-03-2018-0009.

59. Sichtmann, C. (2007). An analysis of antecedents and consequences of trust in a corporate brand, European. Journal of Marketing, 41 (9/10), 999-1015.

60. Siddiqi, K.O. (2011). Interrelations between Service Quality Attributes, Customer Satisfaction and Customer Loyalty in the Retail Banking Sector in Bangladesh. International Journal of Business and Management, 6 (3), 12-36.

61. Singarimbun, M., dan Effendi, S. (2009). Metode Penelitian Survey. Jakarta: LP3ES.

62. Swaid, S. I. and Wigand, R. T. (2007). Key dimensions of e-commerce service quality and its relationships to satisfaction and loyalty. 20th Bled eConference eMergence: Merging and Emerging Technologies, Processes, and Institutions, Bled-Slovenia.

63. Swanson, S.R. and Hsu, M.K. (2009). Critical incidents in tourism: failure, recovery, customer switching, and word-of-mouth behaviors. Journal of Travel \& Tourism Marketing, 26 (2), 180-194.

64. Virgilio, F.D., and Antonelli, G. (2017). Consumer behavior, trust, and electronic word-ofmouth communication: Developing an online purchase intention model. IGI Global, 58-80. 
65. Walsh, G., Hennig-Thurau, T., Bornemann, D., and Sassenberg, K. (2010). Does relationship quality matter in E-services? A comparison of online and offline retailing. Journal of Retailing Consumer Services, 17 (2), 130-142.

66. Wang. Y., Lo, H.P., and Hui, Y.V. (2003). The antecedents of service quality and product quality and their Influences on bank reputation: Evidence from the banking industry in China. Managing Service Quality: An International Journal, 13 (1), $72-83$.

67. Weisberg, J., Te'eni, D. and Arman, L. (2011). Past purchase and intention to purchase in e-commerce: The mediation of social presence and trust. Internet Research, 21 (1), 82-96

68. Wen, C., Prybutok, V. R., and Xu, C. (2011). An integrated model for customer online repurchase intention. Journal of Computer Information System, 52 (1), 14-23.

69. Wolfinbarger, M.F., and Gilly, M.C. (2003). eTailQ: dimensionalizing, measuring and predicting etail quality. Journal of Retailing, 79 (3), 183-198.

70. Yang, F.X. (2017). Effects of restaurant satisfaction and knowledge sharing motivation on eWOM intentions: the moderating role of technology acceptance factors. Journal of Hospitality \& Tourism Research, 41 (1), 93-127.

71. Yap, B. W., Ramayah, T., and Wan Shahidan, W. N. (2012). Satisfaction and trust on customer loyalty: a PLS approach. Business Strategy Series, 13(4), 154-167.

72. Yeh, Y.S. and Li, Y.M. (2009). Building trust in m-commerce: contributing from quality and satisfaction. Online Information Review, 33 (6), 1066-1086.

73. Zeithaml, V.A., Parasuraman, A., and Malhotra, A. (2002). Service quality delivery through websites: a critical review of extant knowledge. Journal of the Academy of Marketing Science, 30 (4), 362-375.

74. Zhang, X. (2009). A model of the relationship among consumer trust, web design and user attributes. Journal of Organizational and End User Computing, 21(2), 44-66.

75. Zhou, T., Lu, Y., and Wang, B. (2009). The relative importance of website design quality and service quality in determining consumers' online repurchase behavior. Information Systems Management, 26 (4), 327-337. DOI: 10.1080/10580530903245663. 